\title{
The metabolite generated by dipeptidyl-peptidase 4 metabolism of glucagon-like peptide-1 has no influence on plasma glucose levels in patients with type 2 diabetes
}

Received: 16 June 2005 / Accepted: 22 August 2005 / Published online: 30 December 2005

(C) Springer-Verlag 2005

\begin{abstract}
Aim/hypothesis: Glucagon-like peptide-1 (GLP-1) is metabolised by the enzyme dipeptidyl-peptidase 4 (DPP-4), generating a metabolite with potential antagonistic properties. This study was conducted to evaluate the effect of that metabolite on plasma glucose levels in patients with type 2 diabetes. Materials and methods: The randomised crossover study consisted of five regimens: (1) i.v. infusion of GLP-1 (1.2 $\mathrm{pmol} \mathrm{kg}^{-1} \mathrm{~min}^{-1}$; IV); (2 and 3) s.c. infusion of GLP-1 (2.4 and $9.6 \mathrm{pmol} \mathrm{kg}^{-1} \mathrm{~min}^{-1}$; LSC, HSC); (4) s.c. infusion of GLP-1 (2.4 pmol kg $\left.\mathrm{min}^{-1}\right)$ in combination with a DPP-4 inhibitor (IB); and (5) s.c. infusion of saline (154 mmol NaCl/l; SAL). Seven patients with type 2 diabetes participated in all protocols. Results: Plasma levels of intact GLP-1 increased from $7 \pm 1$ (SAL) to $17 \pm 3$ (LSC), $61 \pm 7$ (IB), $62 \pm 5$ (IV) and $94 \pm 10$ (9.6 s.c.) pmol/1, $p<0.0001$. Plasma concentrations of the metabolite increased from $1 \pm 3$ (SAL) and $2 \pm 6$ (IB) pmol/1 to $42 \pm 4$ (LSC), $64 \pm 8$ (IV) and $327 \pm 16$ (HSC) $\mathrm{pmol} / 1, p<0.0001$. Mean plasma glucose levels at $6 \mathrm{~h}$ decreased from $12.4 \pm 1.1$ (SAL) $\mathrm{mmol} / \mathrm{l}$ to $10.4 \pm 1.1$ (LSC), $8.6 \pm 0.6$ (IB), $8.8 \pm 0.8$ (IV) and 9.1 \pm 0.9 (HSC) mmol/l, $p<0.0001$. Conclusions/interpretation: At approximately similar concentrations of intact GLP-1 (IV, IB, HSC), but with widely ranging metabolite concentrations, the effect on plasma glucose levels was equal, indicating that the presence of the metabolite does not antagonise the glucose-lowering effect of GLP-1.
\end{abstract}

Keywords Dipeptidyl-peptidase 4 - Glucagon · Glucagon-like peptide-1 · Glycaemic control · Insulin · Metabolism - Metabolite $\cdot$ Treatment $\cdot$ Type 2 diabetes

M. Zander $(\bowtie) \cdot$ S. Madsbad

Department of Endocrinology, Hvidovre Hospital,

Kettegaards Allé 30,

2650, Hvidovre, Denmark

e-mail: m.zander@dadlnet.dk

Tel.: +45-3963-3309

M. Zander · C. F. Deacon · J. J. Holst

Department of Medical Physiology, University of Copenhagen,

The Panum Institute,

Copenhagen, Denmark
Abbreviations DPP-4: dipeptidyl-peptidase 4 - GLP-1: glucagon-like peptide-1 - HSC: s.c. infusion of 9.6 pmol GLP-1 kg-1 $\mathrm{min}^{-1} \cdot$ IB: s.c. infusion of 2.4 pmol GLP-1 $\mathrm{kg}^{-1}$ $\min ^{-1}$. IV: i.v. infusion of $1.2 \mathrm{pmol} \mathrm{GLP}-1 \mathrm{~kg}^{-1} \mathrm{~min}^{-1}$. LSC: s.c. infusion of 2.4 pmol GLP-1 kg-1 $\mathrm{min}^{-1}$. SAL: subcutaneous infusion of saline $(154 \mathrm{mmol} \mathrm{NaCl} / \mathrm{l})$

\section{Introduction}

The intestinal hormone glucagon-like peptide-1 (GLP-1) is currently under investigation for its potential use as a new agent for treatment of type 2 diabetes [1], but since it is a peptide, oral administration is not feasible, and most studies have, therefore, been carried out with i.v. and s.c. infusions [2-4]. S.c. bolus injections of GLP-1 have shortlasting effects on plasma glucose levels [5], presumably due to the rapid degradation and elimination of the peptide [6]. GLP-1 is metabolised by the enzyme dipeptidylpeptidase 4 (DPP-4), generating a truncated metabolite, GLP-1(9-36)-amide [6, 7], which in in vitro studies involving cloned human pancreatic GLP-1 receptors has been shown to bind to the receptor without activating it, suggesting that it may act as an antagonist [8]. However, the metabolite has a binding affinity of only $1 \%$ compared with intact GLP-1 [8]. Nevertheless, in vivo studies in pigs have shown that it can antagonise the inhibitory effect of intact GLP-1 upon gastric emptying [9], and GLP-1 inhibition of gastric emptying is supposed to contribute to the postprandial glucose-lowering effect of GLP-1 [10]. On the other hand, in anaesthetised pigs physiological concentrations of the metabolite influenced neither basal nor GLP-1stimulated insulin secretion, and even exhibited an intrinsic glucose-lowering capacity, which appeared to be independent of insulin [11]. The use of DPP-4 inhibitors to reduce GLP-1 degradation was proposed as a therapeutic approach for type 2 diabetes $[6,12]$, and DPP-4 inhibition has been shown to improve glucose tolerance and insulin secretion in rodents [13, 14] and pigs [15] and to enhance beta cell survival and islet neogenesis in diabetic rats [16]. Furthermore, in clinical studies, DPP-4 inhibition for 4 weeks 
improved glycaemic control in patients with type 2 diabetes [17-19]. These effects could arise as a result of increased levels of intact GLP-1 as well as reduced levels of the potentially antagonistic metabolite, or as a combination of two. Thus, the consequences of the generation of the DPP-4mediated metabolite during GLP-1 treatment of patients with type 2 diabetes remains unclear.

\section{Subjects, materials and methods}

Seven patients (four men and three women) with type 2 diabetes diagnosed after the age of 40 years participated in the study. The patients were 60 (range 51-64) years old with a BMI of 35 (range 28-38) $\mathrm{m} / \mathrm{kg}^{2}$. The mean duration of the disease was 6 (range 4-9) years. Two patients were treated with a combination of sulfonylurea and metformin, three patients were treated with metformin alone, and one patient with sulphonylurea alone. One patient was on dietary therapy. Oral antidiabetic medication was discontinued 3 weeks in advance of the study. Mean fasting glucose level after discontinuation of medication was $11.5 \pm 1.1 \mathrm{mmol} / 1$.

The protocol was approved by the ethical committee of Copenhagen, Denmark, and all patients gave oral and written consent before participation.

The study was designed as a randomised crossover study consisting of five treatment regimens: (1) i.v. infusion of GLP-1 (1.2 pmol kg-1 $\mathrm{min}^{-1}$; IV); (2) continuous s.c. infusion of GLP-1 (2.4 pmol kg-1 $\mathrm{min}^{-1}$; LSC); (3) continuous s.c. infusion of GLP-1 $\left(2.4 \mathrm{pmol} \mathrm{kg}^{-1} \mathrm{~min}^{-1}\right)$ in combination with oral administration of a DPP-4 inhibitor (IB); (4) continuous s.c. infusion of saline (SAL); and (5) continuous s.c. infusion of GLP-1 (9.6 pmol kg-1 $\mathrm{min}^{-1}$; HSC). All patients received all five treatment regimens in randomised order, with each treatment regimen being separated by a washout period of at least 2 days. The patients arrived at the hospital at 17:00 hours; they received dinner and then fasted overnight. GLP-1 infusion (the patients were equipped with a portable insulin pump: MiniMed 506, Medtronic Diabetes, Northridge, CA, USA) was initiated immediately after dinner and continued until the end of the examinations the following day at 14:00 hours. The DPP-4 inhibitor was given as capsules of NVP DPP 728 (a gift from Novartis, Basel, Switzerland) $100 \mathrm{mg} \times 4$ (after dinner at 18.00 hours and at 24:00, 06:00 and at 12:00 hours). After the overnight fast, breakfast was provided at 08:00 hours (time zero) and lunch $4 \mathrm{~h}$ thereafter, with meals being identical in amount and composition on all five regimens. The patients rated sensations of nausea and well-being on $100-\mathrm{mm}$ visual analogue scales before and after breakfast and lunch, as well as $2 \mathrm{~h}$ after breakfast. Blood samples were drawn as a 13-point measurement. The first two blood samples were drawn immediately before breakfast (time zero) and thereafter every $30 \mathrm{~min}$ for $6 \mathrm{~h}$. Blood was distributed into sodium fluoride tubes for plasma glucose, into EDTA tubes for GLP-1 and glucagon, and into heparin tubes for insulin and C-peptide determinations. Trasylol (500 kIU/ml blood; Bayer, Leverkusen, Germany) and valine pyrrolidide $(10 \mu \mathrm{mol} / \mathrm{l}$ blood, a DPP-IV inhibitor used to prevent post-sampling degradation of GLP-1; a gift from R. D. Carr, NovoNordisk, Bagsvaerd, Denmark) were added to the EDTA tubes, and Trasylol was added to the heparin tubes. The tubes were immediately chilled in ice and centrifuged at $4^{\circ} \mathrm{C}$ for $20 \mathrm{~min}$. Plasma for insulin and C-peptide analyses was stored at $-80^{\circ} \mathrm{C}$. Plasma for glucagon and GLP-1 analyses was stored at $-20^{\circ} \mathrm{C}$.

GLP-1(7-36)-amide was produced as a custom synthesis by Polypeptides, Wolfenbüttel, Germany. The correctness of structure and the purity of the peptide $(>98 \%)$ were ascertained by HPLC, mass spectrometry and sequence analysis. For s.c. infusions, the peptide was dissolved in an acetate and D-mannitol buffer ( $\mathrm{pH} 4.7$ ), and diluted with water to give the final concentrations. For i.v. infusion, GLP-1 was dissolved in a sodium phosphate buffer, and human albumin $(20 \%)$ was added to give a final albumin concentration of $5 \%$. The peptide solution was subjected to sterile filtration, dispensed into glass ampoules and stored frozen under sterile conditions until use.

Plasma glucose concentrations were analysed using a Beckman Analyzer (Beckman Instruments, Fullerton, CA,
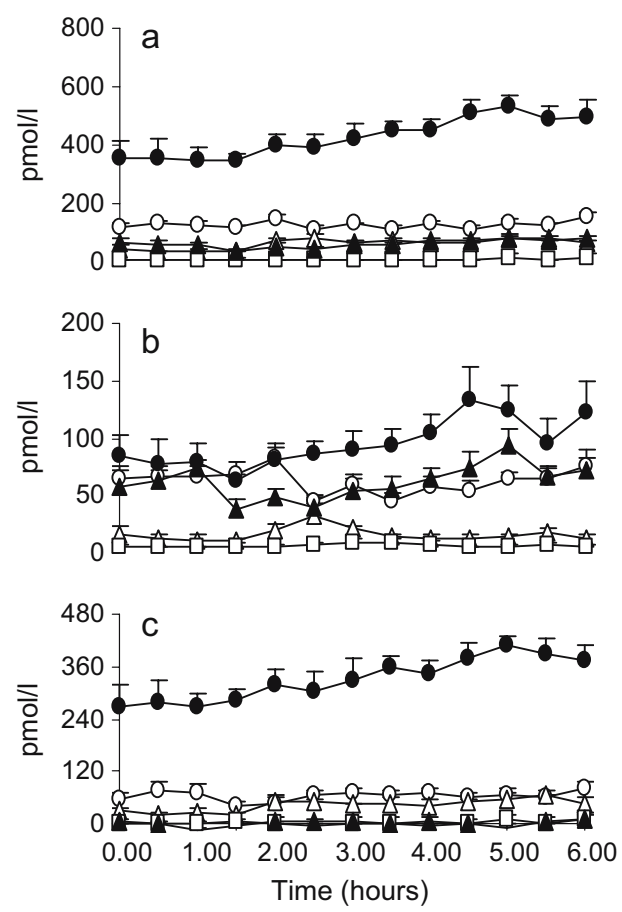

Fig. 1 Plasma concentrations of total GLP-1, intact GLP-1 and the GLP-1 metabolite. Meal ingestion was at 0 and $4 \mathrm{~h}$. Open circles: IV; open triangles: LSC; open squares: SAL; solid triangles: IB; solid circles: HSC. Plasma concentrations of total GLP-1 (a) increased during GLP-1 infusions compared to saline infusion, $p<0.0001$. There was no difference between mean levels of total GLP-1 in LSC and IB groups $(p>0.05)$, whereas the other levels differed significantly $(p<0.05)$. b Plasma concentrations of intact GLP-1 increased during GLP-1 infusions compared to saline infusion, $p<0.0001$. There were no differences between intact GLP-1 in IV and IB groups $(p>0.05)$, whereas the other levels differed significantly $(p<0.05)$. In the first $2 \mathrm{~h}$ of the 6 -h profile, no differences were observed between IV, IB and HSC $(p>0.05)$. c There was no difference in plasma concentrations of the GLP-1 metabolite in the SAL and IB groups $(p>0.05)$, but metabolite levels increased on the LSC, IV and HSC groups 
Table 1 Plasma concentrations of GLP-1 and glucose

\begin{tabular}{|c|c|c|c|c|c|c|c|c|c|c|}
\hline & \multicolumn{2}{|c|}{$\begin{array}{l}\text { Total GLP-1 } \\
(\mathrm{pmol} / \mathrm{l})\end{array}$} & \multicolumn{2}{|c|}{$\begin{array}{l}\text { Intact GLP-1 } \\
(\mathrm{pmol} / \mathrm{l})\end{array}$} & \multicolumn{2}{|c|}{$\begin{array}{l}\text { GLP-1 } \\
\text { metabolite } \\
(\mathrm{pmol} / \mathrm{l})\end{array}$} & \multicolumn{4}{|c|}{ Glucose $(\mathrm{mmol} / \mathrm{l})$} \\
\hline & Fasting & $\begin{array}{l}0-6 \mathrm{~h} \\
\text { mean }\end{array}$ & Fasting & $\begin{array}{l}0-6 \mathrm{~h} \\
\text { mean }\end{array}$ & Fasting & $\begin{array}{l}0-6 \mathrm{~h} \\
\text { mean }\end{array}$ & Fasting & $\begin{array}{l}\text { 6-h } \\
\text { mean }\end{array}$ & $\begin{array}{l}\text { Postprandial glucose } \\
\text { excursion } \\
\text { (0-3 h post breakfast) }\end{array}$ & $\begin{array}{l}\text { Postprandial glucose } \\
\text { excursion } \\
\text { (4-6 h post lunch) }\end{array}$ \\
\hline IV & $122 \pm 13^{\mathrm{ab}}$ & $127 \pm 7^{\mathrm{ab}}$ & $64 \pm 8^{\mathrm{ac}}$ & $62 \pm 5^{\mathrm{ac}}$ & $58 \pm 10^{\mathrm{b}}$ & $64 \pm 8^{b}$ & $8.8 \pm 0.8^{\mathrm{acd}}$ & $8.8 \pm 0.8^{\mathrm{acd}}$ & $1.1 \pm 2^{\mathrm{cd}}$ & $2.0 \pm 0.6^{\mathrm{cd}}$ \\
\hline LSC & $46 \pm 10$ & $62 \pm 4$ & $16 \pm 7$ & $17 \pm 3$ & $30 \pm 8$ & $42 \pm 4$ & $9.9 \pm 1$ & $10.4 \pm 1.1$ & $4.3 \pm 1.5$ & $2.5 \pm 0.8$ \\
\hline SAL & $5 \pm 1$ & $8 \pm 2$ & $6 \pm 2$ & $7 \pm 1$ & $0 \pm 1$ & $1 \pm 3$ & $11.6 \pm 1.1$ & $12.4 \pm 1.1$ & $4.4 \pm 0.9$ & $3.5 \pm 9$ \\
\hline IB & $64 \pm 14$ & $63 \pm 6$ & $57 \pm 16$ & $61 \pm 7$ & $7 \pm 4$ & $2 \pm 6$ & $8.1 \pm 0.6$ & $8.6 \pm 0.6$ & $3.5 \pm 1.1$ & $1.0 \pm 0.5$ \\
\hline HSC & $354 \pm 59$ & $421 \pm 17$ & $84 \pm 18$ & $94 \pm 10$ & $270 \pm 47$ & $327 \pm 16$ & $8.8 \pm 1$ & $9.1 \pm 0.9$ & $2.2 \pm 1.5$ & $2.0 \pm 1.1$ \\
\hline
\end{tabular}

${ }_{a}^{a} p<0.05$ for difference between GLP-1 treatment and saline

${ }^{\mathrm{b}} p<0.05$ for difference between IV and the IB and HSC groups

${ }^{c} p>0.05$ for no difference between IV and IB

${ }^{d}>0.05$ for no difference between IV and the IB and HSC groups

USA). The CV was $2 \%$ for intra-serial analysis and $4 \%$ for inter-serial analysis.

Glucagon was measured by RIA employing antibody code no. 4305 [20].

Total GLP-1 was measured by RIA employing antiserum code no. 89390 [21], which is highly specific for the amidated COOH-terminus of GLP-1 and therefore measures the sum of GLP-1(7-36) amide and its metabolite, GLP-1(9-36)amide. Concentrations of intact GLP-1 were measured using an $\mathrm{NH}_{2}$-terminally directed antibody (code no. 93242) [22]. The concentrations of the metabolite, GLP-1 (9-36)amide, were calculated by subtraction of the concentrations of intact GLP-1 from the concentrations of total GLP-1 for each individual plasma sample. For glucagon and GLP-1 analysis, plasma was extracted with ethanol (final concentration $70 \%, \mathrm{v} / \mathrm{v}$ ) before analysis. Detection limits and intra-assay CV of the assays used were $1 \mathrm{pmol} / 1$ and $<6 \%$ for both assays.

Insulin and C-peptide concentrations were measured using autoDELFIA immunoassay (Wallac Oy, Turku, Finland). The detection limits of the assays are $<5 \mathrm{pmol} / 1$ for insulin and $<50 \mathrm{pmol} / 1$ for C-peptide. Intra- and interassay CV were $4-5 \%$ at $39-700 \mathrm{pmol} / 1$ for insulin and 5$6 \%$ at 355-3700 pmol/1 for C-peptide. The cross-reactivity was $0.1 \%$ with intact proinsulin, $0.4 \%$ with $32-33$ split proinsulin, and $66 \%$ with Des $64-65$ split proinsulin in the insulin assay. In the C-peptide assay, cross-reactivity was $51 \%$ with intact proinsulin, $35 \%$ with $32-33$ split proinsulin, and 92\% with Des 64-65 split proinsulin.

Data are presented as means \pm 1 SEM. Data were analysed by repeated measurement ANOVA followed by Tukey post hoc test (GraphPad Instat version 3 for Windows; GraphPad, San Diego, CA, USA). The first $p$ value indicates the overall results of repeated-measures ANOVA. Significant differences between groups as demonstrated by the Tukey post hoc test are indicated after the first $p$ value. $p$ values $<0.05$ were considered significant.

\section{Results}

Plasma levels of GLP-1 are shown in Fig. 1 and Table 1. During the saline infusion, total GLP-1 concentrations increased in response to meal ingestion (from $\sim 5$ to $\sim 11 \mathrm{pmol} / 190 \mathrm{~min}$ after the first meal and from $\sim 6$ to $\sim 16 \mathrm{pmol} / \mathrm{l} 60 \mathrm{~min}$ after the second meal).

In order to determine whether there were differences in GLP-1 metabolism between i.v. and s.c. administration, the ratios between the mean concentrations during the 13-point profile of intact GLP-1 and total GLP-1 were calculated. This ratio was $0.50 \pm 0.05$ during i.v. infusion, and decreased by half during s.c. infusion, to $0.26 \pm 0.04$ (LSC) and $0.22 \pm 0.02$ (HSC), $p=0.0007$. There was no difference between the ratios obtained during the two s.c. infusions.

Plasma glucose levels are shown in Fig. 2 and Table 1. The reductions in plasma glucose levels (the difference from saline) were $3.6 \pm 0.6$ (IV), $2.0 \pm 0.5$ (LSC), $3.8 \pm 0.7$ (IB) and $3.3 \pm 0.7$ (HSC) mmol/l, $p=0.03$, with the IV, IB and HSC treatments achieving significantly greater reductions than LSC. From Table 1 it can be seen that at the same plasma levels of intact GLP-1, fasting plasma glucose levels, mean plasma glucose levels during the day and the

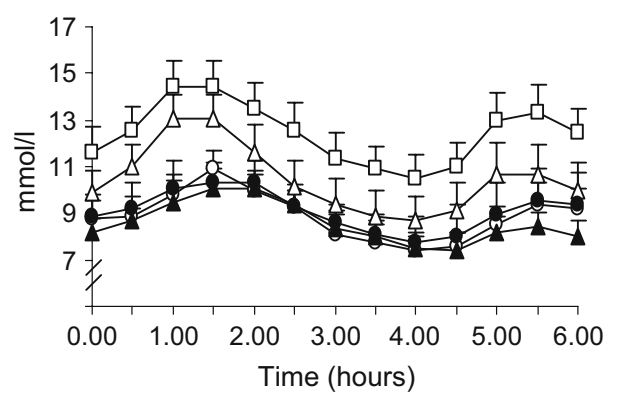

Fig. 2 Plasma glucose levels. Meal ingestion was at 0 and $4 \mathrm{~h}$. Open circles: IV; open triangles: LSC; open squares: SAL; solid triangles: IB; solid circles: HSC. Fasting and 6-h mean plasma glucose levels were reduced by GLP-1 infusions compared to saline infusion, $p<0.01$. IV, IB and HSC treatments achieved greater reductions than $\mathrm{LSC}, p=0.03$ 
Table 2 Sensation of nausea and plasma concentrations of insulin, C-peptide and glucagon

\begin{tabular}{|c|c|c|c|c|c|c|c|}
\hline \multirow[t]{2}{*}{ Treatment } & \multicolumn{2}{|c|}{ Insulin (pmol/l) } & \multicolumn{2}{|c|}{ C-peptide (pmol/l) } & \multicolumn{2}{|c|}{ Glucagon (pmol/1) } & \multirow{2}{*}{$\begin{array}{l}\text { Sensation of nausea (mm on VAS) } \\
0-6 \mathrm{~h} \text { mean }\end{array}$} \\
\hline & Fasting & 0-6 h mean & Fasting & 0-6 h mean & Fasting & 0-6 h mean & \\
\hline IV & $106 \pm 21$ & $130 \pm 21$ & $1544 \pm 197^{\mathrm{a}}$ & $1916 \pm 221$ & $7.4 \pm 1.7$ & $7.0 \pm 0.7$ & $14.6 \pm 10.2$ \\
\hline LSC & $79 \pm 19$ & $117 \pm 14$ & $1293 \pm 140$ & $1768 \pm 166$ & $7.2 \pm 1.6$ & $8.1 \pm 0.9$ & $4.9 \pm 1.7$ \\
\hline SAL & $60 \pm 10$ & $119 \pm 19$ & $1030 \pm 129$ & $1642 \pm 219$ & $8.4 \pm 1.1$ & $9.7 \pm 1$ & $4.3 \pm 1.4$ \\
\hline IB & $85 \pm 15$ & $124 \pm 22$ & $1376 \pm 166^{\mathrm{a}}$ & $1863 \pm 252$ & $6.9 \pm 0.7$ & $6.7 \pm 0.4$ & $19.2 \pm 11.6$ \\
\hline HSC & $87 \pm 15$ & $124 \pm 19$ & $1539 \pm 133^{\mathrm{a}}$ & $1975 \pm 229$ & $7.7 \pm 1.2$ & $7.0 \pm 0.6$ & $33.8 \pm 11.1^{\mathrm{b}}$ \\
\hline
\end{tabular}

$V A S$ visual analogue scale

${ }_{\mathrm{a}} p=0.0009$ for difference between the IV, IB and HSC groups and saline

${ }^{\mathrm{b}} p=0.02$ for difference between the HSC group and SAL and LSC

postprandial glucose excursions were similar for all treatments, despite widely ranging metabolite concentrations.

Plasma concentrations of insulin,C-peptide and glucagon are shown in Table 2. Sensations of nausea are also shown in Table 2.

\section{Discussion}

In the present study, we investigated the consequences of DPP-4-mediated GLP-1 metabolism on metabolic control in patients with type 2 diabetes. We used the DPP-4 inhibitor NVP DPP 728 (Novartis) to prevent GLP-1 degradation (and hence metabolite formation), together with different GLP-1 infusions, in order to achieve different levels of intact GLP-1 and metabolite. This inhibitor has been demonstrated to provide extensive inhibition of GLP-1 degradation and significant improvement of glycaemic control in patients with type 2 diabetes [17]. We found that at the same concentration of intact GLP-1 ( $60 \mathrm{pmol} / \mathrm{l})$, the reductions in plasma glucose levels were the same in spite of a wide range of concomitant metabolite concentrations. Thus, the metabolite seems to have no influence on GLP-1-induced changes in plasma glucose levels. Similarly, neither glucagon nor insulin levels were influenced by the metabolite concentration. In vitro studies have shown that the metabolite acts as an antagonist towards the pancreatic GLP-1 receptor, albeit binding to the receptor with an affinity of $<1 \%$ compared with intact GLP-1 [8]. However, in vivo studies in anaesthetised pigs have shown that the metabolite does not elicit antagonistic effects towards insulin secretion, even when present in 30fold higher concentrations compared with intact GLP-1, and the metabolite even appeared to possess an intrinsic glucose-lowering effect [11]. Judging from the present data in humans, the metabolite does not seem to possess any glucose-lowering effect, or to have any antagonistic effect upon the metabolic control achieved by intact GLP-1. These interpretations are supported by a recently published study in healthy humans, in which it was shown that GLP-1 -induced insulin release and glucose metabolism is not influenced by the metabolite [23]. In addition, another study in mice has indicated that the metabolite is not involved in the regulation of glucose homeostasis [24]. The metabolite has been demonstrated to antagonise the action of GLP-1 on gastric motility [9], but in recent studies in our laboratory infusions of large amounts of the metabolite (resulting in a plasma concentration $\sim 600 \mathrm{pmol} / \mathrm{l}$ ) had no effect on gastric emptying of a liquid meal (C. F. Nagell and J. J. Holst, unpublished results). In the present study the metabolite had no influence on the postprandial glucose excursions. An effect of the metabolite on gastric emptying is therefore unlikely to have influenced the results. DPP-4 has substrates other than GLP-1, e.g. gastric inhibitory peptide; therefore, DPP-4 inhibition will also inhibit gastric inhibitory peptide degradation. However, gastric inhibitory peptide is completely ineffective in type 2 diabetes $[25$, $26]$. Therefore, one would not expect a protection of gastric inhibitory peptide to influence glycaemia in the present study. In addition, in experiments in DIRKO mice (mice with double knock-out of the GLP-1 and gastric inhibitory peptide receptors), DPP-4 inhibitors have no effect on glycaemia or insulin secretion, indicating that GLP-1 and gastric inhibitory peptide are the most important substrates for DPP-4 with regard to glucose metabolism [27].

GLP-1 is currently under investigation for its potential therapeutic use as a new agent for treatment of type 2 diabetes. Being a peptide hormone, oral administration is not possible and as i.v. infusions are inconvenient, alternative therapeutic approaches have involved s.c. injections. In the present study, we found that GLP-1 was more extensively degraded when given s.c. compared with i.v. The metabolite accounted for $50 \%$ of the total GLP-1 concentration during i.v. infusion compared with $70-80 \%$ during s.c. infusion. It has previously been reported that the metabolite accounts for more than $80 \%$ of total GLP- 1 after a single s.c. injection of native GLP-1 [6]. This might be explained by enzymatic activity in the subcutis and in the s.c. capillaries. S.c. injections of GLP-1 may, therefore, be an inexpedient way of GLP-1 administration. On the other hand, as long as sufficiently high plasma concentrations of intact GLP-1 are achieved, the generation of the metabolite does not seem to create problems with regard to reaching acceptable glycaemic control. Inhibition of GLP-1 degradation by DPP-4 inhibition has also been proposed as a therapeutic approach $[6,12]$. DPP-4 inhibition has been shown to improve glucose tolerance and insulin secretion in rodents [13, 14] and pigs [15], as well as glycaemic control in patients with type 2 diabetes [17, 18]. These effects, therefore, as discussed above, seem to be due to 
increased levels of intact GLP-1 and not, as previously speculated, because of reduced levels of antagonistic metabolite. In line with this, we found that plasma levels of intact GLP-1 increased when GLP-1 infusion (2.4 pmol kg-1 $\mathrm{min}^{-1}$ ) was combined with DPP-4 inhibition, and we found a concomitant reduction in plasma glucose levels. Thus, combination therapy with GLP-1 and a DPP-4 inhibitor may have therapeutic advantages as a way of achieving higher plasma levels of intact GLP-1 and, thereby, a more efficacious reduction in plasma glucose levels.

We have previously shown that plasma glucose levels are efficaciously reduced in patients with type 2 diabetes by continuous s.c. infusion of GLP-1 [4]. In that study, the treatment period was 6 weeks, the infusion rate was $4.8 \mathrm{pmol} \mathrm{kg}^{-1} \mathrm{~min}^{-1}$ and plasma glucose levels were reduced by $\sim 6 \mathrm{mmol} / 1$ after 1 week as well as 6 weeks of infusion. In the present study we increased the infusion rate to $9.6 \mathrm{pmol} \mathrm{kg}^{-1} \mathrm{~min}^{-1}$, but plasma glucose was reduced by only $3 \mathrm{mmol} / \mathrm{l}$. It may be speculated, therefore, that the full glucose-lowering effect of s.c.-infused GLP-1 is not seen acutely, but requires at least 1 week of infusion.

We found that plasma glucose levels were equally reduced with infusion of GLP-1, resulting in plasma concentrations of intact GLP-1 of 60 and 90 pmol/l. In addition, both infusions were more efficacious than infusions resulting in levels of $20 \mathrm{pmol} / \mathrm{l}$. Thus, a maximal effect of GLP-1 appears to be reached with plasma concentrations of intact GLP-1 between 20 and $60 \mathrm{pmol} / \mathrm{l}$. High concentrations of intact GLP-1 may cause downregulation of GLP-1 receptor function [28], explaining why increasing doses of GLP-1 may give no further advantage. Furthermore, the increases in plasma concentrations of intact GLP-1 above $60 \mathrm{pmol} / \mathrm{l}$ were associated with a significantly higher incidence of nausea. Thus, this level of intact GLP-1 may delineate not only the maximal therapeutic effect, but may also be the level where side effects begin to appear. It should be noted, however, that GLP-1 has been shown to stimulate beta cell replication and neogenesis, and to inhibit apoptosis of beta cells $[29,30]$. Thus, long-term GLP-1 treatment may have additional beneficial effects compared with short-term treatment.

In conclusion, we found that the antihyperglycaemic effects of GLP-1 depend upon the plasma concentration of intact hormone, whereas the metabolite seems to have no influence, either as an independent glucose-reducing factor or as an antagonist to the glucose-lowering effect of the intact hormone. Furthermore, GLP-1 was more extensively metabolised in the subcutis than the vascular bed. GLP-1 in combination with a DPP-4 inhibitor efficaciously increases the plasma concentration of intact GLP-1, making this combination a potential therapeutic approach.

Acknowledgements We thank S. Reimer, Hvidovre Hospital, for technical assistance. The study was supported by the Danish Diabetes Association and the Danish Medical Research Council.

\section{References}

1. Nauck MA, Meier JJ, Creutzfeldt W (2003) Incretins and their analogues as new antidiabetic drugs. Drug News Perspect $16: 413-422$

2. Nauck MA, Kleine N, Orskov C, Holst JJ, Willms B, Creutzfeldt W (1993) Normalization of fasting hyperglycaemia by exogenous glucagon-like peptide 1 (7-36 amide) in type 2 (non-insulindependent) diabetic patients. Diabetologia 36:741-744

3. Rachman J, Gribble FM, Barrow BA, Levy JC, Buchanan KD, Turner RC (1996) Normalization of insulin responses to glucose by overnight infusion of glucagon-like peptide 1 (736) amide in patients with NIDDM. Diabetes 45:1524-1530

4. Zander M, Madsbad S, Madsen JL, Holst JJ (2002) Effect of 6week course of glucagon-like peptide 1 on glycaemic control, insulin sensitivity, and beta-cell function in type 2 diabetes: a parallel-group study. Lancet 359:824-830

5. Ritzel R, Orskov C, Holst JJ, Nauck MA (1995) Pharmacokinetic, insulinotropic, and glucagonostatic properties of GLP-1 [7-36 amide] after subcutaneous injection in healthy volunteers. Dose-response relationships. Diabetologia 38:720-725

6. Deacon CF, Nauck MA, Toft-Nielsen M, Pridal L, Willms B, Holst JJ (1995) Both subcutaneously and intravenously administered glucagon-like peptide I are rapidly degraded from the $\mathrm{NH}_{2}$-terminus in type II diabetic patients and in healthy subjects. Diabetes 44:1126-1131

7. Deacon CF, Johnsen AH, Holst JJ (1995) Degradation of glucagon-like peptide-1 by human plasma in vitro yields an $\mathrm{N}$-terminally truncated peptide that is a major endogenous metabolite in vivo. J Clin Endocrinol Metab 80:952-957

8. Knudsen LB, Pridal L (1996) Glucagon-like peptide-1-(9-36) amide is a major metabolite of glucagon-like peptide-1-(7-36) amide after in vivo administration to dogs, and it acts as an antagonist on the pancreatic receptor. Eur J Pharmacol 318:429-435

9. Wettergren A, Wojdemann M, Holst JJ (1998) The inhibitory effect of glucagon-like peptide-1 (7-36)amide on antral motility is antagonized by its N-terminally truncated primary metabolite GLP-1 (9-36)amide. Peptides 19:877-882

10. Willms B, Werner J, Holst JJ, Orskov C, Creutzfeldt W, Nauck MA (1996) Gastric emptying, glucose responses, and insulin secretion after a liquid test meal: effects of exogenous glucagon-like peptide-1 (GLP-1)-(7-36) amide in type 2 (noninsulin-dependent) diabetic patients. J Clin Endocrinol Metab 81:327-332

11. Deacon CF, Plamboeck A, Moller S, Holst JJ (2002) GLP-1(9-36) amide reduces blood glucose in anesthetized pigs by a mechanism that does not involve insulin secretion. Am J Physiol Endocrinol Metab 282:E873-E879

12. Holst JJ, Deacon CF (1998) Inhibition of the activity of dipeptidyl-peptidase IV as a treatment for type 2 diabetes. Diabetes 47:1663-1670

13. Ahren B, Holst JJ, Martensson H, Balkan B (2000) Improved glucose tolerance and insulin secretion by inhibition of dipeptidyl peptidase IV in mice. Eur J Pharmacol 404:239-245

14. Balkan B, Kwasnik L, Miserendino R, Holst JJ, Li X (1999) Inhibition of dipeptidyl peptidase IV with NVP-DPP728 increases plasma GLP-1 (7-36 amide) concentrations and improves oral glucose tolerance in obese Zucker rats. Diabetologia 42:1324-1331

15. Deacon CF, Hughes TE, Holst JJ (1998) Dipeptidyl peptidase IV inhibition potentiates the insulinotropic effect of glucagonlike peptide 1 in the anesthetized pig. Diabetes 47:764-769

16. Pospisilik JA, Martin J, Doty T et al (2003) Dipeptidyl peptidase IV inhibitor treatment stimulates beta-cell survival and islet neogenesis in streptozotocin-induced diabetic rats. Diabetes 52:741-750 
17. Ahren B, Simonsson E, Larsson H et al (2002) Inhibition of dipeptidyl peptidase IV improves metabolic control over a 4week study period in type 2 diabetes. Diabetes Care 25:869-875

18. Ahren B, Landin-Olsson M, Jansson PA, Svensson M, Holmes D, Schweizer A (2004) Inhibition of dipeptidyl peptidase-4 reduces glycemia, sustains insulin levels, and reduces glucagon levels in type 2 diabetes. J Clin Endocrinol Metab 89:2078-2084

19. Ahren B, Gomis R, Standl E, Mills D, Schweizer A (2004) Twelve- and 52-week efficacy of the dipeptidyl peptidase IV inhibitor LAF237 in metformin-treated patients with type 2 diabetes. Diabetes Care 27:2874-2880

20. Orskov C, Jeppesen J, Madsbad S, Holst JJ (1991) Proglucagon products in plasma of noninsulin-dependent diabetics and nondiabetic controls in the fasting state and after oral glucose and intravenous arginine. J Clin Invest 87:415-423

21. Orskov C, Rabenhoj L, Wettergren A, Kofod H, Holst JJ (1994) Tissue and plasma concentrations of amidated and glycineextended glucagon-like peptide I in humans. Diabetes 43:535-539

22. Gutniak MK, Larsson H, Heiber SJ, Juneskans OT, Holst JJ, Ahren B (1996) Potential therapeutic levels of glucagon-like peptide I achieved in humans by a buccal tablet. Diabetes Care 19:843-848

23. Vahl TP, Paty BW, Fuller BD, Prigeon RL, D'Alessio DA (2003) Effects of GLP-1-(7-36)NH2, GLP-1-(7-37), and GLP$1-(9-36) \mathrm{NH}_{2}$ on intravenous glucose tolerance and glucoseinduced insulin secretion in healthy humans. J Clin Endocrinol Metab 88:1772-1779

24. Rolin B, Deacon CF, Carr RD, Ahren B (2004) The major glucagon-like peptide-1 metabolite, GLP-1-(9-36)-amide, does not affect glucose or insulin levels in mice. Eur J Pharmacol 494:283-288
25. Nauck MA, Heimesaat MM, Orskov C, Holst JJ, Ebert R, Creutzfeldt W (1993) Preserved incretin activity of glucagonlike peptide 1 [7-36 amide] but not of synthetic human gastric inhibitory polypeptide in patients with type-2 diabetes mellitus. $\mathrm{J}$ Clin Invest 91:301-307

26. Vilsboll T, Krarup T, Madsbad S, Holst JJ (2002) Defective amplification of the late phase insulin response to glucose by GIP in obese type II diabetic patients. Diabetologia 45:11111119

27. Hansotia T, Baggio LL, Delmeire D et al (2004) Double incretin receptor knockout (DIRKO) mice reveal an essential role for the enteroinsular axis in transducing the glucoregulatory actions of DPP-IV inhibitors. Diabetes 53:1326-1335

28. Fehmann HC, Jiang J, Pitt D, Schweinfurth J, Goke B (1996) Ligand-induced regulation of glucagon-like peptide-I receptor function and expression in insulin-secreting beta cells. Pancreas $13: 273-282$

29. Xu G, Stoffers DA, Habener JF, Bonner-Weir S (1999) Exendin-4 stimulates both beta-cell replication and neogenesis, resulting in increased beta-cell mass and improved glucose tolerance in diabetic rats. Diabetes 48:2270-2276

30. Hui H, Nourparvar A, Zhao X, Perfetti R(2003) Glucagon-like peptide-1 inhibits apoptosis of insulin-secreting cells via a cyclic 5'-adenosine monophosphate-dependent protein kinase A- and a phosphatidylinositol 3-kinase-dependent pathway. Endocrinology 144:1444-1455 